\title{
Implementasi Pemuridan Kontekstual Untuk Meningkatkan Spiritualitas dan Sikap Konsisten dalam Melakukan Firman Bagi Remaja Masa Kini di Gereja Toraja Jemaat
}

Komba

Oleh:

\author{
Betzi Patanduk \\ Institut Agama Kristen Negeri Toraja \\ Email: bpatanduk@gmail.com
}

\begin{abstract}
ABSTRAK _ Di zaman yang serba modern ini, pemuda remaja semakin lupa dengan apa yang seharusnya mereka kerjakan sebagai generasi penerus. Kewajiban kita sebagai generasi pemuda remaja adalah belajar, patuh pada orangtua dan juga agama, namun harapan ini hanya tinggal harapan, karena sangat berbeda dengan fakta kehidupan anak muda remaja sekarang ini, mereka lebih mementingkan hura-hura (hedonis) dan mengikuti hawa nafsu daripada menjalankan kewajibannya. Pemuridan kontekstual ini menjadikan anak remaja semakin mengenal Allah' hidup dalam Tuhan dan senantiasa memiliki sikap yang konsisten melakukan firman-Nya, agar remaja tidak hilang dari gereja dan terus memiliki identitas sebagai remaja Kristen. Makalah ini bertujuan untuk mengetahui implementasi pemuridan kontekstual untuk meningkatkan sikap konsisten dan disiplin dalam melakukan firman bagi remaja di gereja Toraja Jemaat Komba.
\end{abstract}




\section{BAB I \\ PENDAHULUAN}

\section{A. Latar belakang}

Pada masa sekarang ini, pemuda sungguh berat tantangan kehidupannya dalam menjalani titian jalan yang lurus yang tidak menyimpang dari norma, adat dan agama. Dilihat dari aktivitas anak-anak muda zaman sekarang ini sungguh sangat memprihatinkan sekaligus sangat disayangkan. Remaja sekarang sudah banyak yang terlibat dalam tindak kriminal, mulai dari pencurian, mabuk-mabukan, penyalahgunaan narkotika, pergaulan bebas, keluyuran tak tentu arah dan tujuan yang jelas dan lain sebagainya.

Pembentukan spiritual bagi anak remaja sangat penting. Dalam hal ini orang tua harus menjadi pemimpin yang baik yaitu pemimpin yang berada ditengah-tengah. ${ }^{1}$ Oleh sebab itu peranan orang tua sangat diperlukan dalam membentuk spiritual remaja yang dimulai dari rumah untuk meyiapkan diri mereka dalam memasuki tahapan kehidupan selanjutnya. Demikian juga halnya dengan peranan gereja (para pembina remaja) sangat penting dalam menolong mereka menemukan jati diri mereka. Kebanyakan remaja sekarang ini aktif pergi ke gereja atau mengikuti ibadah remaja dan kegiatan rohani lainnya bahkan melayani di dalam gereja. Namun semuanya itu mereka lakukan hanya secara seremonial atau sekedar rutinitas. Mereka tidak memiliki sikap konsisten dalam melakukan firman yang disampaikan dalam ibadah di gereja. Akibatnya sikap spiritualitas mereka tidak terbentuk dengan baik dan benar. Sebagaimana yang dikatakan dalam Yakobus 1:22-25.

Bila pembina rohani remaja tidak mengarahkan mereka ke jalan yang benar, maka di waktu yang mendatang tidak ada lagi remaja yang mempunyai spiritual yang baik. Oleh sebab itu, penting bagi pembina remaja di gereja memberikan ajaran yang benar dan didikan yang tepat dalam meningkatkan sikap konsisten melakukan firman, agar mereka mengikuti ibadah, mendengar firman atau mengikuti kegiatan di gereja

\footnotetext{
${ }^{1}$ Roswitha Ndraha dan Julianto Simanjuntak, 9 Masalah Utama Remaja (Jakarta:Yayasan Peduli Konseling Indonesia, 2009), 8.
} 
bukan hanya sebagai rutinitas atau seremonial, tetapi mereka juga harus melakukan firman sesuai ajaran Yesus Krisus.

\section{B. Rumusan Masalah}

Berdasarkan latar belakang masalah yang didapat maka adapun rumusan masalah dalam makalah ini yaitu bagaimana implementasi pemuridan kontekstual untuk meningkatkan sikap konsisten dalam melakukan firman bagi remaja di gereja Toraja jemaat Komba?

\section{Tujuan}

Adapun tujuan dari makalah ini, yaitu untuk mengetahui bagaimana implementasi pemuridan kontekstual untuk meningkatkan sikap konsisten dalam melakukan firman bagi remaja di gereja Toraja jemaat Komba.

\section{Manfaat}

- Membantu setiap pembaca khususnya kepada orang tua dan pembina remaja/ guru sekolah minggu kelas remaja mengetahui bagaimana pentingnya membangun spiritualitas dan menamkan serta mengarahkan anak remaja masa kini tetap memiliki sikap konsisten melakukan firman.

- Agar tulisan ini dapat menjadi pegangan bagi penulis dalam pelayanan ke depan untuk meningkatkan spiritualitas remaja Kristen masa kini. 


\section{BAB II \\ PEMBAHASAN}

\section{A. Pengertian Pemuridan}

Kata murid lebih sering dipakai daripada Kristen untuk merujuk orang yang percaya di dalam Alkitab. Penggunaan yang berulangkali ini memberitahu kita bahwa murid adalah kategori mendasar bagi orang-orang Kristen. Kita pertama-tama adalah murid, baru kemudian orang tua, pegawai, pendeta, penatua, diaken, dan suami atau istri. Murid adalah sebuah identitas. Semua hal yang lain adalah peran. Peran kita sementara, tetapi identitas kita akan bertahan selamanya. ${ }^{2}$ Pemuridan adalah "suatu proses hubungan antara seorang pengikut Kristus yang lebih dewasa serta berpengalaman dan beberapa orang yang baru percaya, lalu ia membagikan kehidupannya (prisip-prinsip kebenaran firman Tuhan, keyakinan, komitmen, waktu, tenaga, perhatian, serta hal lain yang diperlukan) demi menolong orang-orang tersebut untuk mengenal Kristus dan pada suatu saat mereka pun akan memperkenalkan Kristus kepada orang lain".3 Dalam bahasa sederhananya pemuridan adalah seseorang yang membagikan kehidupannya bagi orang lain yang baru percaya demi menolong mereka untuk mengenal dan memperkenalkan Kristus.

\section{B. Pengertian Pemuridan Kontekstual (KTBK)}

Pemuridan kontekstual adalah model pemuridan yang menggunakan konteks sebagai pertimbangan utama. Dalam hal ini baik teks Alkitab maupun pembuat muridnya, kebutuhan rohani, dan lingkungannya. Metode pemuridan ini memakai nama KTBK atau Contextual Bible Group (CBG). Pemimpin dalam KTBK merupakan pemimpin yang bersifat interdependensi, anggota dan pemimpin saling tergantung satu sama lain. Mereka adalah tubuh Kristus yang rohaninya tumbuh bersama, saling membutuhkan, saling menolong, saling mengasihi dan saling melayani. Anggota pemuridan KTBK sangat efektif pada petobat-petobat baru yang mau bertumbuh ke arah Kristus ataupun orang

\footnotetext{
${ }^{2}$ Jonathan K. Dodson, Pemuridan yang Berpusatkan Injil (

${ }^{3}$ Herdy N. Hutabarat, Mentoring \& Pemuridan: Anda Juga Bisa (Bandung: Yayasan Kalam Hidup, 2011) hal. 75.
} 
percaya secara umum. Petobat baru akan bertumbuh lebih efektif menjadi seorang murid Kristus dan menuju dewasa serupa Yesus Kristus, melalui KTBK ini. ${ }^{4}$

Proses KTBK adalah meneladani persekutuan orang percaya yaitu:

- Dalam belajar Firman Allah (learning), untuk bertumbuh menuju kedewasaan penuh dan menjadi serupa dengan Kristus dibutuhkan pengajaran Firman Tuhan yang disertai kerelaan dalam menaati otoritas Firman Tuhan. Proses belajar dalam KTBK dilakukan bersama dengan memahami Alkitab secara indukstif kontekstual.

- Penyembahan dan doa. Penyembahan merupakan respon seseorang untuk memuji dan membesarkan nama Tuhan. Penyembahan juga mengingatkan akan perbuatan-perbuatan Tuhan dan kasih setia-Nya. Anggota KTBK lebih mengenal Allah melalui unsur penyembahan sehingga KTBK dan unsur penyembahan tidak dapat dipisahkan. Penyembahan bisa dilakukan melalui doa, puji-pujian, dan puisi yang berisi puji-pujian.

- Persekutuan (fellowship). Persekutuan kasih yang terjadi diantara anggota KTBK akan menyaksikan kepada orang lain bahwa mereka benar-benar murid Kristus. Gereja mula-mula membentuk persekutuan karena mereka telah mengalami keselamatan dari Tuhan dan menyadari pentingnya persekutuan. Persekutuan dalam KTBK akan menolong semua anggota dapat saling mengasihi, saling melayani, saling membangun, saling memperhatikan, saling menasehati, membagikan kebutuhannya masing-masing, saling mengakui dosa-dosanya, saling menanggung beban, membesarkan hati orang lain dan saling mendoakan.

- Pengutusan (missions). Pengutusan adalah kesaksian anggota KTBK untuk pergi memberitakan Injil Yesus Kristus kepada orang-orang yang membutuhkannya. Melalui pengutusan ini anggota KTBK dapat

\footnotetext{
${ }^{4}$ T Haryono and Daniel Fajar Panuntun, "Andil Pemuridan Kontekstual Yesus Kepada Petrus Yakobus Dan Yohanes Terhadap Keterbukaan Konseling Mahasiswa Pada Masa Kini," Gamaliel : Teologi dan praktika 1, no. 1 (2019): 17-18.
} 
mempraktikkan kasih dan kuasa Allah. oleh sebab itu, KTBK terkait erat dengan pengutusan. ${ }^{5}$

\section{Remaja}

Masa remaja merupakan masa peralihan antara masa kehidupan anak-anak dan masa kehidupan orang dewasayang ditandai dengan pertumbuhan dan perkembangan biologis dan psikologis. Secara biologis ditandai dengan tumbuh dan berkembangnya seks primer dan seks sekunder sedangkan secara psikologis ditandai dengan sikap dan perasaan, keinginan dan emosi yang labil atau tidak menentu. ${ }^{6}$ Masa remaja ditandai dengan sejumlah karakteristik penting yang meliputi pencapaian hubungan yang matang dengan teman sebaya, dapat menerima dan belajar peran sosial sebagai pria atau wanita dewasa yang dijunjung tinggi oleh masyarakat, menerima keadaan fisik dan mampu menggunakannya secara efektif, mencapai kemandirian emosional dari orang tua dan orang dewasa lainnya, memilih dan mempersiapkan karier dimasa depan sesuai dengan minat dan kemampuannya, mengembangkan keterampilan intelektual dan konsep-konsep yang diperlukan sebagai warga negara, mencapai tingkah laku yang bertanggung jawab secara sosial dan memperoleh seperangkat nilai dan sistem etika sebagai pedoman dalam bertingkah laku. $^{7}$

Perkembangan pada hakikatnya adalah usaha penyesuaian diri (coping), yaitu untuk secara aktif mengatasi stress dan mencari jalan keluar dari berbagai masalah yang dihadapi. Sehingga dalam tataran perkembangan remaja, penyesuaian diri menjadi sangat penting. Kemampuan penyesuai diri yang sehat terhadap lingkungan merupakan salah satu prasyarat yang penting bagi terciptanya kesehatan jiwa atau mental individu. Banyak remaja yang menderita dan tidak mampu mencapai kebahagian dalam hidupnya karena ketidakmampuannya dalam menyesuaikan diri baik dalam kehidupan keluarga, sekolah, pekerjaan maupun masyarakat pada umumnya.

\footnotetext{
${ }^{5}$ Ibid, 18.

${ }^{6}$ Khoirul Bariyyah Hidayati and M Farid, “Konsep Diri, Adversity Quotient dan Penyesuaian Diri pada Remaja," Persona: Jurnal Psikologi Indonesia, no. 02 (Mei 2016): 137.

${ }^{7}$ Idid, 137-138.
} 


\section{Spiritualitas Remaja}

Masa remaja merupakan suatu kelangsungan hidup dari tahap-tahap kehidupan yang harus dilalui manusia. Pada masa sekarang ini kaum remaja mulai menghilang dari gereja, identitas mereka sebagai remaja Kristen juga menghilang. Melihat hal tersebut maka pembentukan spiritual bagi anak remaja sangat penting. Pembentukan spiritualitas anak remaja tidak hanya di bentuk melalui keluarga. Meskipun keluarga adalah tempat pertama membentuk spiritual anak remaja namun gereja juga merupakan tempat pembentukan spiritualitas anak remaja. Peranan gereja (para pembina remaja) sangat penting dalam menolong mereka menemukan jati diri mereka. Remaja butuh dihargai, diterima, dimengerti, dan diperhatikan. Karena dimasa kini ada banyak bahaya yang dapat muncul menggagalkan kehidupan spiritual remaja apabila orang tua dan pembina remaja tidak membangun kehidupan spiritual remaja tersebut.

Dalam pembentukan spiritualitas oleh para pembina remaja/ guru kepada anak remaja, tentu harus berjalan berbarengan dengan sikap yang mencerminkan Kristus yang setia melakukan Firman-Nya. Pada masa kini kebanyak gereja sudah merasa puas bila melihat para remajanya aktif pergi ke Gereja atau mengikuti ibadah remaja dan kegiatan rohani lainnya bahkan melayani di dalam gereja. Namun bila semuanya mereka lakukan hanya secara seremonial, atau sekedar rutinitas bahkan hanya ikut-ikutan saja, maka remaja tersebut tidak akan mendapatkan apa-apa, alias kehidupan spiritualnya tidak terbentuk dengan baik dan benar. Sebagaimana yang dikatakan dalam Yakobus 1:22-25 "Tetapi hendaklah kamu menjadi pelaku firman dan bukan hanya pendengar saja; sebab jika demikian kamu menipu diri sendiri. Sebab jika seorang hanya mendengar firman saja........."

Masih banyak remaja Kristen yang lahir dalam keluarga Kristen bahkan rajin mengikuti ibadah dan kegiatan rohani juga ambil bagian dalam pelayanan di gereja, kehidupan rohaninya tidak terbentuk secara benar dan sering berada pada krisis moral. Pemuridan kontekstual dilakukan agar remaja Kristen tidak ikut arus tetapi dapat menjadikan anak remaja semakin mengenal Tuhan dan dapat hidup bertumbuh di hadapan Allah dalam Yesus Kristus. Dalam pemuridan yang dilakukan kepada remaja Kristen menjadi pelaku firman atau tetap konsisten dalam melakukan firman harus terus 
ditanamkan dan diajarkan dalam diri anak remaja. Bukan hanya melakukan kegiatan rohani atau mendengar Firman tetapi juga dibarengi dengan sikap yang konsisten menghidupi Firman Tuhan. 


\section{BAB III \\ PENUTUP}

\section{A. Kesimpulan}

Membangun spiritual remaja dan tetap menanamkan sikap konsisten melakukan firman bagi remaja ialah suatu upaya yang terus menerus untuk mendemonstrasikan hidup yang berarti atau bermakna dengan menjaga dan memelihara iman remaja supaya dapat mengambil sikap dan keputusan dalam realitas hidup di tengah-tengah kesempatan dan tantangan kehidupan. Masa remaja adalah masa transisi dari dunia kanak-kanak yang telah ditinggalkan, tetapi masa kedewasaan belum dijalani dengan sungguh-sungguh. Itu sebabnya dalam membangun spiritualitas remaja diperlukan orang-orang dewasa yang kompeten seperti orang tua dan gereja. Dalam mendidik kerohanian remaja diperlukan peran orang dewasa dalam hal ini pembina remaja. Oleh sebab itu gereja perlu menyediakan seorang pembina remaja/guru yang memiliki rasa kepedulian terhadap remaja.

\section{B. Saran}

Selain pendidikan rohani dirumah yang sangat diperlukan bagi remaja, maka gereja menjadi tempat kedua bagi remaja untuk dididik agar dapat bertumbuh secarah utuh. Oleh sebab itu gereja perlu menyediakan seorang pembina remaja yang berkualitas, menyediakan fasilitas persekutuan remaja yang memadai dan memberikan programprogram bagi remaja yang menarik dan efektif untuk meningkatkan spiritualitas anak remaja dan senantiasa melakukan firman-Nya. Penulis juga menyarankan agar pemerhati remaja dan rindu melayani remaja masa kini, agar mendidik mereka dengan kasih dan sesuai dengan kehendak Tuhan. 


\section{DAFTAR PUSTAKA}

Dodson, Jonathan K. Pemuridan yang Berpusatkan Injil. Jakarta: Perkantas, 2012.

Gunarsa, Singgih D. dan Dra. Yulia Singgih D. Gunarsa. Psikologi Perkembangan Anak dan Remaja. Jakarta: Gunung Mulia, 2008.

Hapsarini, Deslana Roidja and Wahyu Suprihati, "PERAN ORANG TUA DALAM MENGEMBANGKAN KECERDASAN SPIRITUAL ANAK DI ERA MASA KINI." Veritas Lux Mea: Jurnal Teologi dan Pendidikan Kristen, no. 2 (2019).

Haryono, T, and Daniel Fajar Panuntun. "Andil Pemuridan Kontekstual Yesus Kepada Petrus Yakobus Dan Yohanes Terhadap Keterbukaan Konseling Mahasiswa Pada Masa Kini.” Gamaliel: Teologi dan praktika 1, no. 1 (2019): 12-25.

Hidayati, Khoirul Bariyyah and M Farid, "Konsep Diri, Adversity Quotient dan Penyesuaian Diri pada Remaja," Persona: Jurnal Psikologi Indonesia, no. 02 (Mei 2016): 137-144.

Hutabarat, Herdy N. Mentoring \& Pemuridan: Anda Juga Bisa Bandung: Yayasan Kalam Hidup, 2011.

Ndraha, Roswitha dan Julianto Simanjuntak, 9 Masalah Utama Remaja . Jakarta: Yayasan Peduli Konseling Indonesia, 2009.

Panuntun, Daniel Fajar, and Eunike Paramita. "HUBUNGAN PEMBELAJARAN ALKITAB TERHADAP NILAI-NILAI ( KELOMPOK TUMBUH BERSAMA KONTEKSTUAL." Gamaliel: Teologi dan praktika 1, no. 2 (2019): 104-115.

Putro, Khamim Zarkasih. "MEMAHAMI CIRI DAN TUGAS PERKEMBANGAN MASA REMAJA." APLIKASIA: Jurnal Aplikasi Ilmu-ilmu Agama, no. 1 (2017): 25-32.

Yuliati, and Kezia Yemima. "MODEL PEMURIDAN KONSELING BAGI ALUMNUS PERGURUAN TINGGI LULUSAN BARU (FRESH GRADUATE) YANG MENGINGKARI PANGGILAN PELAYANAN" 1, no. 1 (2019): 26-40. 